given for air concentrations in various sites and conditions, and the dose to the lungs of city dwellers estimated on the basis of measurements of air content of elosed rooms.

The final paper, by Dr. W. P. Grove (Radiochemical Centre, Amersham), described experience with the measurement of radon in breath, a method which is specific to radium. The procedure for obtaining a representative sample of breath was described and details given of a technique for collecting the charged active deposit electrically on a metal foil coated with a phosphor for scintillation counting. Several cases had been sent to Leeds for total $\gamma$-measurement, and comparison with the exhaled radon suggested an excretion of about 60 per cent.

Reviewing the whole meeting with special reference to external methods of measuring body radioactivity, it could be concluded generally that scintillation techniques have reduced the limits of detection of 'hard' $\gamma$-emitters from figures of the order of $2 \times 10^{-9}$ c. in a 2 -hr. observation with ion chambers to about $10^{-10} \mathrm{c}$. obtainable in $15 \mathrm{~min}$.; and that $\beta$-emitters such as phosphorus-32 can be detected at levels of the order of $3 \times 10^{-8} \mathrm{c}$. Detection of levels of this latter order appears to be possible for a weak $\gamma$-emitter such as americium-24i.

It was generally agreed that the success of the conference was in large measure due to its informality and to the many opportunities for discussion it afforded. Delegates were entertained by the Board of Governors of the United Leeds Hospital during the scientific sessions held in the Leeds General Infirmary, and also by the University of Leeds at a dinner at which the vice-chancellor, Sir Charles Morris, presided.

It is hoped in due course to publish in full the proceedings of the conference in a single volume.

G. W. REED

1 Recommendations of the International Commission on Radiological Protection, Brit. J. Radiol., Supp., 6 (1955). ${ }^{2}$ Sievert, R. M., Strahlentherapie, 99, 185 (1956).
${ }^{3}$ Hultqvist, B., Kungl. Svenska Vetenskapsakademiens Handlingar, 6,

${ }^{4}$ Rundo, J., J. Sci. Instr., 32, 379 (1955).

5 Burch, P. R. J., and Spiers, F. W., Nature, 172, 519 (1953).

${ }^{6}$ Anderson, E. C., et al., Nucleonics, 14, 26 (1956).

${ }^{7}$ Hursh, J. B., and Gates, A. A., Nucleonies, 7, 46 (1950).

${ }^{8} \mathrm{Krebs}$, A. T., Strahlentherapie, 72, 164 (1942).

- Spiers, F. W., Brit. J. Radiol., 26, 296 (1953).

\title{
ECOLOGY AND NATURE CONSERVATION
}

A MOST successful meeting was held in Edinburgh during June $20-28$ by the International Union for the Conservation of Nature and Natural Resources, hitherto known by the misleadingly restricted title of International Union for the Protection of Nature. There was an excellent attendance both of animal and plant ecologists, and of administrators, engineers, town-and-country planners, foresters and other interested professions. More than thirty countries were represented. Among the visiting scientists were : Prof. Roger Heim (president of the Union), director of the Paris National Museum of Natural History, and Profs. J. G. Baer (Neuchatel), E. Beltran (Mexico), H. Gams (Innsbruck), T. Monod (Dakar), and Dr. Ira Gabrielson (United States) (all members of the executive board), and also Profs. J. Berlioz and F. Bourlière (Paris), Prof. G. P. Dementiev and Dr. L. K. Shaposhnikov (U.S.S.R. Academy of Sciences), Dr. W. Engelhardt (Munich), Dr. E. H. Graham (United States Soil Conservation Service), Dr. A. Marcello (Italy), Prof. G. J. Van Oordt, Mr. M. F. MorzerBruyns, and Dr. V. Westhoff (Netherlands), Mr. Fairfield Osborn (president of the U.S. Zoological Society and the Conservation Foundation), $\mathrm{Mr}$. Roger Tory Peterson (United States), Mr. Hugh M. Raup (director of Harvard Forest, U.S.A.), Mr. F. N. Ratcliffe (Australia), Prof. L. G. Romell (Sweden), Prof. R. Sparek (Copenhagen), Prof. W. Szafer (Poland), Prof. V. E. van Straelen (Belgium) and Dr. E. B. Worthington (Africa).

A number of directors and other officers of national parks, nature reserves, forests, and interested societies also attended, including : Mr. J. H. Baker (executive director of the U.S. National Audubon Society), Mr. H. H. Bennett (recently chief of the U.S. Soil Conservation Service), Mr. M. C. Bloemers (director of the Netherlands Government Nature Protection Department), Mr. H. J. Coolidge (director of the Pacific Science Board), Mr. R. de Vilmorin (president of the French Société d'Acclimatation), M. F. Edmond. Blane (secretary general of the Conseil Internationale de la Chasse), M. J-P. Harroy (Governor of Ruanda Urundi), Mr. R. Knobel (director of national parks, South Africa) and M. F. Vidron (secretary general of the Conseil Supérieure de la Chasse, France).

The United Kingdom was represented, among others, by Profs. W. H. Pearsall, P. W. Richards, M. L. Anderson and R. Matthew, and by Mr. A. B. Duncan, Sir Basil Neven Spence, Mr. E. M. Nicholson, Dr. F. Fraser Darling and a number of members of the staff of the Nature Conservancy, and representatives of the National Coal Board, the National Parks Commission, the North of Scotland HydroElectric Board, the Forestry Commission, and a number of other public authorities and government departments, together with Lord Hurcomb (president), and other representatives of the Society for the Promotion of Nature Reserves, Mr. Peter Scott (director) and members of the research staff of the Wildfowl Trust, Capt. Keith Caldwell and Lieut.-Col. C. L. Boyle (Fauna Preservation Society), and others.

The meeting was notable in bringing together for the first time picked representatives of so many different professions, whose activities affect land use and management, and who are increasingly feeling the need for a concerted approach to their problems. For this purpose the agenda of the technical meeting consisted of four topics, three of which related to land use :

(1) Management of nature reserves on the basis of modern scientific knowledge. This subject elicited several important papers. Ecologically, one of the most interesting was Mr. Raup's reconstruction, based on nearly fifty years of organized studies by Harvard University, of the relation of present to past woodlands in eastern North America. Briefly, he held that the conception of a stable climax forest is an illusion (even where there is no human interference), and that natural catastrophes, particularly wind-throw during storms, and also fire, occur within the life-span of most trees on most areas-while climatic and other environmental changes keep the 
vegetation from settling down on any one consistent pattern. He compared the process with the similarly drastic effects of frost action on the arctic tundra, and he demonstrated techniques of tracing, through woodland soil profiles, storm havoc going back so far as four hundred years.

Dr. Ira Gabrielson gave an excellent summary of United States techniques in nature reserve management, and Mr. E. M. Nicholson submitted a detailed review of the principles of management of natural areas, based on a comparison between European and North American practice.

Brief mention must also be made of Prof. Romell's valuable analysis of the extensive man-made elements in Scandinavian habitats, and the Wildfowl 'Trust's review of aspects of the management of wildfowl refuges in Britain.

Mr. Fairfield Osborn presided over these sessions, with Dr. F. Fraser Darling as rapporteur. Unfortunately, the number of participants in this section was too large to permit adequate discussion.

(2) The second theme was devoted to an international comparison of the course and repercussions of myxomatosis in rabbits, and a critical review of factors affecting its future development. Mr. F. N Ratcliffe, who presided, described the ecological consequences of myxomatosis in Australia, and Prof. Bourlière, the rapporteur, ably summed up the remarkably consistent experience of different countries, as shown by the papers describing the effects on the French, British and Netherland flora, and on predatory and competing animals, particularly in Britain.

Mr. H. V. Thompson (Ministry of Agriculture, Fisheries and Food) expressed the personal view that in England the rabbit population may, provided there are sustained efforts at control, be held down to roughly a fifth of its level before myxomatosis. The relationship between the more virulent and less virulent strains of the virus, and the considerations affecting possible repeated use of the virus among rabbit populations which have already been attacked by it, were fully reviewed.

(3) The third theme was a return to land-use problems, with special reference to the rehabilitation of areas biologically devastated by human disturb. ances. Dr. R. Lessing (London) initiated a lively discussion on colliery refuse and mining subsidence. He stated that the present method of surface disposal of colliery refuse means waste, nuisance and damage, and that the National Coal Board will soon be sterilizing nearly 1,000 acres a year, worth between $£ 50,000$ and $£ 100,000$, by covering it with some 40 million tons of mined refuse containing an estimated fuel value equivalent to that of nearly $10,000,000$ tons of coal; much of this could be utilized by the design and installation of suitable plant, which has now been shown to be technically practicable. At the same time, compensation for subsidence resulting from the bringing of this material to the surface is estimated at $£ 3,000,000$ a year; this could be prevented or minimized by storage underground of solid material. Naturally these conclusions proved controversial and were in particular criticized by a representative of the National Coal Board. The meeting concluded that, after reviewing a wide range of specialized evidence on the practice, the time has come for all governments concerned to initiate official technical investigations in order: $(a)$ to determine whether this type of spoil should not in future be disposed of underground in order to avoid the serious waste of land, fuel and other natural resources which it involves ; $(b)$ to fix time limits within which either the practice of dumping should cease or the matter should be further reviewed; (c) to examine the possibility of dealing by legislation or otherwise with existing spoil heaps of this type.

In contrast, the North of Scotland Hydro-Electric Board was warmly congratulated by delegates for its successful efforts to reconcile hydro-electric development with preservation of amenities, and of the fauna and flora. The Board's work was inspected on the ground during a visit to the Pitlochry and Tummel areas.

The joint consideration by ecologists, engineers, and land planners of a number of problems arising from large civil engineering works produced some of the most interesting discussions, and it was generally agreed that much greater efforts should be made in future to ensure that the knowledge and advice of ecologists were sought at an early stage by governments, and by agencies undertaking works capable of altering the landscape.

The chairman for this theme was Prof. W. H. Pearsall, and the rapporteur was Dr. W. Engelhardt.

(4) The fourth, and closely related, theme dealt broadly with the relationship of ecology with landscape planning, with Mr. R. J. Bentham, chief of the Landscape Department of the Netherlands State Forest Service, as rapporteur.

Dr. E. H. Graham contributed an important paper on Nature protection as part of land development, based on extensive American experience. Some interesting papers were contributed from Germany on ecological landscape management in torrent catchment areas, and on the protection of Nature in relation to structure of landscape.

Mr. A. Glikson, an architect from Israel, contributed a thoughtful review of the relationship between landscape planning and ecology, and discussions also took place on other aspects, such as the making and use of vegetation surveys, and the part played by shelter belts in land use, on which the discussion was opened by Prof. M. L. Anderson (Edinburgh).

So far as it is possible to summarize in a few words the results of so much diverse discussion, it may be said that a start has at last been made towards creating the long-needed link between ecology and the various technologies, arts and industries concerned in or affecting its application to landscape. Aesthetic, scientific and economic considerations all have to be reconciled in any satisfactory treatment, and hitherto they have been largely isolated from one another. We are still a long way from being able to formulate any theory to reconcile these conflicting approaches; but we can at least now see that the methods in general use to-day fall far short of the best modern practice and are in too many cases producing serious or even disastrous long-term consequences. The first remedial steps must be to educate the authorities and individuals concerned not to cling to a few favoured methods (such as burning of heather, surface dumping of mining refuse, or shooting of predators), but to turn their attention to the desired results (for example, improved grazing, getting rid of unwanted materials, or maintaining game populations) and to rely on trained scientists to find the best methods for getting these results. There is a close parallel here to the role of research in the Defence Services, where again it has been necessary to show that victory only comes from readiness to replace preconceived and cherished methods by newer and more appropriate 
ones. World-wide comparisons are particularly fruitful in the conservation field, and they show clearly that even government agencies and large undertakings are still clinging to methods equivalent to the bow-and-arrow stage in warfare. Both the International Union and national conservation agencies will need to be strengthened to find the right answers and to see that they are put into practice. The high technical quality of the Edinburgh meeting and the impressive representation of the various professions concerned gives encouragement to believe that they will not fail.

The meeting was accompanied by an international film week, at which a wide range of films was shown from countries as far apart as India, Japan, the U.S.S.R., South Africa and Canada, illustrating the increasing potentialities of colour films for scientific as well as education and propaganda purposes. The effects of fire, erosion, pollution and destruction of plant and animal life were vividly illustrated. One general comment was that in too many cases the skill and thoroughness exhibited in obtaining the pictures was not yet matched when it came to cutting and editing the material. As a result of these comments, progiess in this direction can be confidently expected.

About 180 photographs of mammals, reptiles, birds, insects and plants were exhibited from the British National Collection of Nature Photographs, newly formed by the Nature Conservancy, and the Royal Scottish Museum arranged an interesting exhibition on "Man and the Balance of Nature" which included a good deal of material from the recent International Exhibition organized by the International Union for the Conservation of Nature and Natural Resources in Paris.

The papers and discussions of the technical meeting will be published as soon as possible, but in the meantime the Nature Conservancy would be glad to reply to any inquiries, addressed to it at 19 Belgrave Square, London, S.W.1.

\section{INTERNATIONAL UNION OF CRYSTALLOGRAPHY}

\section{MEETINGS IN MADRID}

$\mathrm{T}$ HE meetings of the International Union of Crystallography held in Madrid during April 2-7 were a departure from the previous practice of the Union in several ways. For the first time, the main interest of the symposium was not focused on structure on a molecular scale, but on structure on a scale intermediate between molecular and opticalmicroscopic. Also for the first time, two of the Commissions of the Union organized an extended series of open meetings. The programme was very crowded, and even with the help of colleagues I am able to give only an incomplete account.

\section{Teaching of Crystallography}

The Congiess of the Union held in Paris in 1954 saw the beginning of the present general interest in the teaching of crystallography and the establishment of a Commission ${ }^{1}$ on such teaching. In preparation for the Madrid meetings, this Commission had circulated a questionnaire, and from the replies and the statements given by several national representatives it was obvious that crystallography, though it grew suddenly out of the morphological stage as long ago as 1912 and has made swift progress since, has not received full academic recognition even yet. Full courses in crystallography at the undergraduate level are extremely rare, and most of the undergraduate teaching given elsewhere is slight and incidental to studies in the older sciences. The best opportunity for serious study of, and training in, crystallography is postgraduate, and the prior training in other subjects is a great advantage. For crystallography embraces a field far wider than is often realized-even by those engaged in other sciences-and far wider than its name suggests. In just over forty years we have gained an insight into the variety of structures, perfect and imperfect, and into the structural reasons for the chemical and physical properties of solids, that far outstrips our knowledge of liquids and gases. This new insight is being rapidly exploited by industry, but scarcely any use has been made of it in modern presentations of the established sciences.
It was generally agreed that, instead of trying to squeeze formal courses on crystallography into the already overcrowded degree courses, it would be both easier and more natural to introduce it incidentally and gradually, thus making the student structureconscious even from his school days. The preciseness of crystal models and the directness of this approach could transform completely much of the teaching of the basic chemical laws, and at the university degree level could simplify the presentation of material in many subjects. In some subjects, such as physics, the emphasis would be less on the diversity of structures and more on the relations between structure and physical properties (especially anisotropic properties), and on diffraction phenomena in two and three dimensions. Mineralogy has had, of course, the closest academic relation with crystallography, but it is remarkable how many departments still concern themselves mainly with morphological and petrological techniques, paying scant attention to structure and its connexions with geochemistry--and (so it would appear from the discussions in Madrid) even less to the techniques of structure analysis. On this point, contributions at the meeting from the U.S.S.R. were especially interesting. The bias of Russia has been traditionally mineralogical, but for the few who undertake the very extensive courses the training is comprehensive and modern. In Europe generally there is great variety in the approach, and the extent of training is dependent on local educational tradition and personal initiative. In North America there are a very few, and very good, schools of crystallographical research and postgraduate teaching, but very little is done at the undergraduate level. Japan is worthy of mention for the scale and quality of its post-war work in crystallography; but it is not clear how far the subject has penetrated into undergraduat. teaching.

The ideas exchanged at Madrid on the order of presentation and on teaching aids were valuable, and showed that, despite the variety of contexts in which the subject is introduced, geometrical concepts are 